\title{
Splenic Red Pulp
}

National Cancer Institute

\section{Source}

National Cancer Institute. Splenic Red Pulp. NCI Thesaurus. Code C12992.

Splenic pulp seen grossly as a reddish brown substance, due to its abundance of red blood cells, consisting of splenic sinuses and the tissue intervening between them (splenic cords). 